\title{
RADIOASTRONOMY
}

\section{DISTRIBUTION OF THE OCCURRENCE OF THE INTENSIVE IONOSPHERE SCINTILLATIONS ON THE OBSERVATIONS OF THE COSMIC RADIO SOURCES AT THE DECAMETER WAVE RANGE}

\author{
O. A. Lytvynenko, S. K. Panishko \\ Observatory URAN-4, Institute of Radio Astronomy NASU \\ Pushkinskaya str., 37, Odessa, 65125, Ukraine, spanishko@ukr.net
}

\begin{abstract}
Effect of scintillations arises in the result of interaction of radio signal from the cosmic radio source with irregularities of ionosphere plasma which appears at the registration of observations as amplitude fluctuations. Wherein fluctuations of the different intensities and with the different long time periods can be observed. Scintillations of large intensity and with large characteristic times (periods) take an interest because its influence on records of the radio sources is very essential and can distort the record shape. In this case there is a need to consider the presence of the intensive fluctuations. In this sense it might be useful to investigate the frequency of occurrence of the intensive scintillation. Processing of the radio sources records was carried out on the observations of power cosmic radio sources at the passage through direction pattern of the radio telescope URAN-4 at frequencies 20 and $25 \mathrm{MHz}$ during 1998-2007. Record's characteristics were obtained including ionosphere scintillation parameters. Also records with scintillations of large intensity and with long periods were marked. In this work daily distribution of intensive scintillations was analyzed. It was showed that occurrence of intensive scintillations changes in limits of $4-26 \%$ and it is larger on the lower frequency. Dependence of occurrence of scintillations from angle between direction on the radio source and line of geomagnetic field in the observation place was found. It was obtained that the maximum of the occurrence of the intensive scintillations for all observed radio sources appears on the nighttime of the day. Also local maximums of frequency of occurrence are exist which may be associated with the moments of sunrise and sunset.
\end{abstract}

Key words: radio source: ionosphere scintillations, decameter range, daily distribution of ionosphere scintillations

АНОТАЦІЯ. Ефект іоносферних мерехтінь виникає в результаті взаємодії радіосигналу від компактного космічного радіоджерела 3 неоднорідностями іоносферної плазми і проявляється при реєстрації спостережень як амплітудні флуктуації. При цьому можуть спостерігатись флуктуації різної інтенсивності і $з$ періодами різної тривалості. Мерехтіння великої інтенсивності і 3 великим характерним часом (періодом) викликають інтерес так як їхній вплив на записи радіоджерел дуже вагомий i вони можуть значно спотворювати форму запису. В такому випадку виникає необхідність враховувати наявність інтенсивних флуктуацій. Тому може бути корисним дослідити частоту появи інтенсивних іоносферних мерехтінь. На радіотелескопі УРАН-4 на частотах 20 i 25 МГц на протязі 1998-2007 років були проведені спостереження потужних космічних джерел 3 реєстрацією у вигляді записів при проходженні через діаграму направленості радіотелескопу, а також виконана обробка отриманих записів. В результаті обробки були отримані характеристики кожного запису в тому числі параметри мерехтінь. При цьому були відмічені записи 3 мерехтіннями великої інтенсивності і з великими періодами. В цій праці проаналізовано добовий розподіл появи інтенсивних мерехтінь. Показано, що частота появи інтенсивних мерехтінь змінюється в інтервалі 4-26\% і їх ймовірність зростає на нижчій частоті. Знайдена залежність частоти появи інтенсивних мерехтінь від кута між напрямком на радіоджерело і силовою лінією геомагнітного поля. Отримано, що максимум частоти появи інтенсивних мерехтінь для всіх спостережуваних радіоджерел проявляється в нічний час. Також існують локальні максимуми, які, скоріше за все, пов'язані з моментами сходу і заходу Сонця.

Ключові слова: радіоджерело: іоносферні мерехтіння, декаметровий діапазон радіохвиль, добовий розподіл іоносферних мерехтінь.

\section{Introduction}

When the signal from the discrete cosmic radio source propagates through Earth's ionosphere it undergoes the amplitude fluctuations caused by interaction with irregularities of ionosphere plasma [Crane R. K., 1977]. Effect of scintillations is particularly essential for observations at the decameter wave range. Wherein amplitude fluctuations can to characterize by different intensities from weak up to saturated and by different characteristic time intervals (periods) from several seconds up to ten minutes. It is reflect the state of irregularity of ionosphere structure in the moment of observations. Scintillations with large intensities and periods take an interest because they largerly distort the observations records of the cosmic radio sources. For example, fluctuations with large periods that comparable with size of radio telescope direction pattern can to distort the shape of records that caused the incorrecting processing results. 
There is a need to take into consideration the presence of the intensive fluctuations at the processing of observations. In this sense it might be useful to investigate the frequency of occurrence of the intensive scintillation. The daily distribution of the intensive scintillations is presented in this work on the observations of the power radio sources at the decameter wave range.

\section{Observations data}

The regular observations of the 4-th power radio sources - 3C144, 3C274, 3C405, 3C461, were carried out on the radio telescope URAN-4 at frequencies 20 and $25 \mathrm{MHz}$ during 1998-2007 [Derevyagin V. G. et al, 2019]. Several records of the passing through RT direction pattern of each radio source were registered during day. Observations data are stored in computer memory in the digital form. After data processing parameters that characterized each record and scintillation parameters were obtained. Under data processing the quality of the record was estimated including the presence or absence of intensive scintillations in form: '0' - absence; '1' - presence. All data processing was placed in the text files in chronological order for each source and on frequencies. The analysis of daily distribution of occurrence of intensive scintillations was fulfilled further on obtained estimations.

Table 1: Statistics of the occurrence of the intensive scintillations for 4-th radio sources at two frequencies during 1998-2007

\begin{tabular}{rrrrrrrrr}
\hline NS & H & D & N20 & S20 & P20 & N25 & S25 & P25 \\
\hline 144 & 66 & 0 & 9881 & 990 & 0.10 & 8194 & 342 & 0.04 \\
\hline 274 & 56 & 10 & 11318 & 1445 & 0.13 & 8859 & 606 & 0.07 \\
\hline 405 & 84 & 19 & 10883 & 1761 & 0.16 & 11790 & 1045 & 0.09 \\
\hline 461 & 77 & 37 & 8354 & 2201 & 0.26 & 8021 & 1177 & 0.15 \\
\hline
\end{tabular}

\section{Analysis and discussion the results on} intensive scintillations

Examples of the records of radio sources with intensive scintillations obtained on radio telescope URAN-4 observations are showed in the Fig. 1 (Fig. 1b and 1c). Record with weak scintillations is demonstrated for comparison (Fig. 1a). Fig. 1 shows that in the case of weak scintillations the processing of record (that include the fitting of smooth curve) can to execute better than in second case and all the more in third case. Proceed from abovementioned it is turns out to be important to know statistics and distribution of occurrence of intensive scintillations.

Data for radio sources that observed is contains in Table 1 at frequencies 20 and $25 \mathrm{MHz}: N$ - total number of records; $S$ - number of records with intensive scintillations; $P=S / N$ - relative value of occurrence of intensive scintillations. Also additional information on radio sources placed into Table 1: $N S$ - number of source in catalogue $3 \mathrm{C}$; $H$ - height of source in culmination moment (degrees); $D$ angle between on source direction and line of geomagnetic field (degrees).
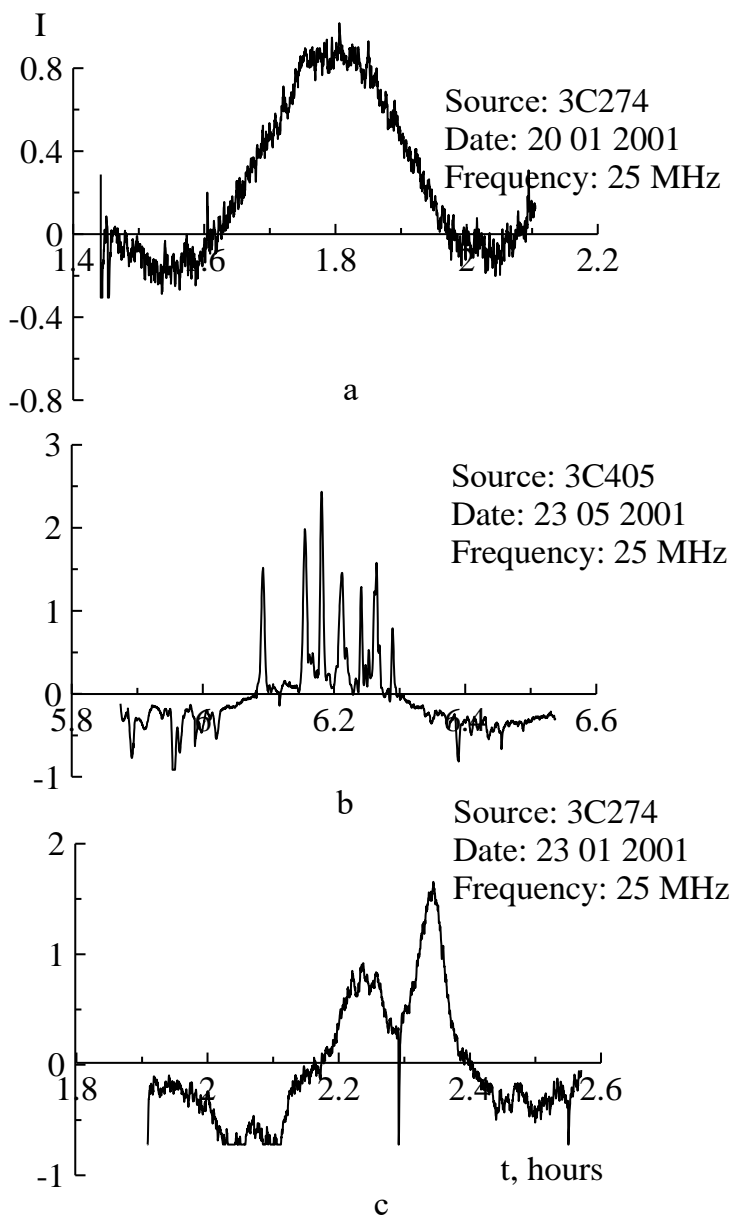

Figure 1: Samples of records of radio sources with scintillations of different intensities. Values of intensity are measured in relative units

Proceed from table data it is possible to say that frequency of occurrence of intensive scintillations changes in limits from 4 up to $26 \%$ and this value is larger almost in two times at $20 \mathrm{MHz}$ than at $25 \mathrm{MHz}$ that corresponds to increase of scintillation effect on lower frequency [Liu C. H. et al., 1986]. Also one can note that occurrence of intensive scintillations do not depends obviously on height on which radio source observed. However the dependence of frequency of scintillation occurrence from angle between on source direction and line of geomagnetic field in observation place (Fig.2) is observes: the larger this angle the higher probability of intensive scintillations. The similar dependence was got in the work [Lytvynenko O. A. et al, 2000] for such parameter of scintillations as period. Inversely proportional dependence exists for the scintillation index. It is demonstrates the role of geomagnetic field in manifestations of irregularity structure of ionosphere [Aarons J., 1982].

In order to analyze the behavior of intensive scintillations occurrence in time the daily distribution of such occasions was obtained by sum up within each hour from 0 up to 24. Distribution that obtained was normalized on maximum value. Result is shown in Fig. 3. 


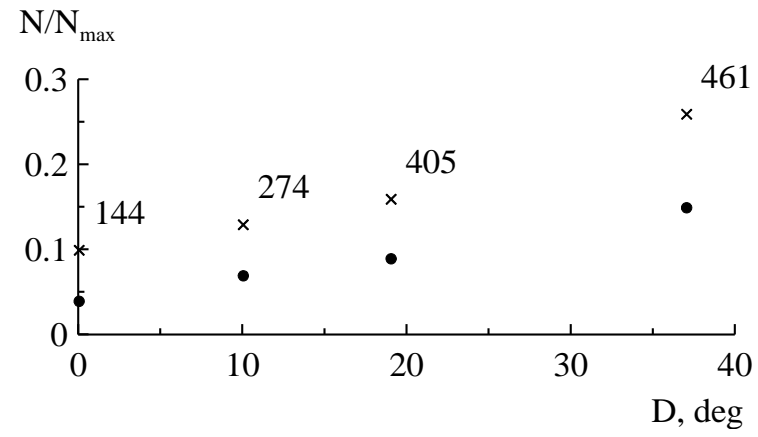

Figure 2:. Dependence of the frequency of occurrence of the intensive scintillations from angle between direction on radio source and line of geomagnetic field in observation place. Data at the frequency $20 \mathrm{MHz}$ marked by crests and at $25 \mathrm{MHz}$ - by circles
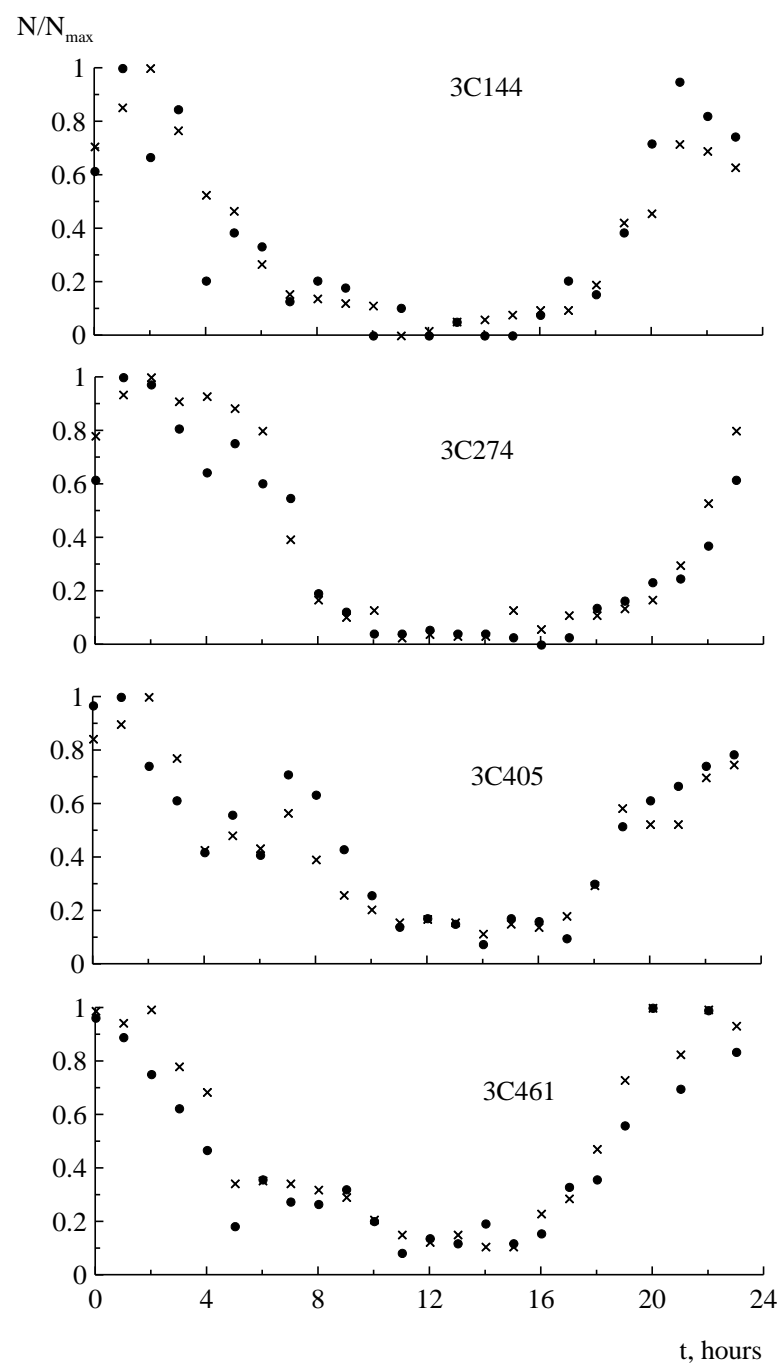

Figure 3: Frequency of the occurrence of intensive scintillations in dependence from time of day for 4-th radio sources at two frequencies; there are presented numbers of occasions divided by maximum value. Marks for two frequencies are correspond to marks in Fig. 2
Daily distribution of the frequency of intensive scintillations occurrence is observes for all radio sources with minimum in daytime and maximum in nighttime. Besides one can note that several local maximums of the frequency occurrence are exist which may be associated with moments of sunrise and sunset.

\section{Conclusions}

The analysis of occurrence of scintillations with large intensity was fulfilled by observations of power cosmic radio sources (3C144, 3C274, 3C405, 3C461) obtained on the radio telescope URAN-4 at the frequencies 20 and 25 MHz during 1998-2007:

1. Frequency of occurrence of intensive scintillations changes in limits from 4 up to $26 \%$.

2. Daily distribution of such scintillations was obtained: minimum observed in daytime and the probability to observe intensive scintillations increased in nighttime.

3. It is shown that relative frequency of intensive scintillations occurrence do not depends obviously from height of radio source observation.

4. The dependence of the frequency of scintillation occurrence from angle between on source direction and line of geomagnetic field in observation place is observes: the larger this angle the higher probability of intensive scintillations.

\section{References}

Crane R.K.: 1977, Proc. IEEE, 65, 180.

Derevyagin V.G. et al.: 2019, DOI: 10.31401/ WS.2019.proc.

Liu C.H. et al.: 1986, Radio Science, 21, 363.

Lytvynenko O.A. et al:: 2000, Geomagnetizm i Aeronomiya, 40, № 4, 116 (in russian).

Aarons J.: 1982, Proc. IEEE, 70, No 4, 360. 